\title{
The Causality Relationship Between Financial Sector Profitability and the Botswana Economy
}

\author{
Tebogo Tshepo Kubanji1 ${ }^{1}$, Simangaliso Biza-Khupe ${ }^{2} \&$ Mogotsinyana Mapharing ${ }^{2}$ \\ ${ }^{1}$ De Beers Botswana, Gaborone, Botswana \\ 2 Department of Accounting and Finance, University of Botswana, Gaborone, Botswana \\ Correspondence: Mogotsinyana Mapharing, Department of Accounting and Finance, University of Botswana, P.O. \\ Box 00701, Gaborone, Botswana Tel: 267-355-2244. E-mail: mapharingm@ub.ac.bw
}

Received: November 4, 2020

Accepted: December 23, 2020

Online Published: February 24, 2021

doi:10.5430/ijfr.v12n3p381

URL: https://doi.org/10.5430/ijfr.v12n3p381

\begin{abstract}
Previous research has lamented on both the importance and the symbiotic relationship between financial sector performance and the state of a country's economy. Findings of these studies are generally in concert in that the performance of the financial sector is intertwined with macroeconomic indicators. There is, however, a difference in opinion on the precise nature of the relationship between these sets of variables. This difference of opinion has led to the development of three parallel strands of theory: demand-driven relationship; supply-driven relationship; and economic developmental stage. To the extent that an understanding of the precise nature of the relationship between these critical variables would promote economic growth, it was found imperative to investigate the phenomenon in the context of a developing economy. This paper examines the causal relationship between the financial sector index and GDP in Botswana. The study uses data over a period of 10 years (2003-2013). This study timeframe is significant because previous research does not incorporate the critical periods in financial markets history over which the global economy experienced the economic cycle of the boom years (2003-2006), followed by a recession (2007-2010) and finally the recovery period (2010 and beyond). This financial cycle provides a unique opportunity for new insights into how financial sector performance relates to the economy. The findings are suggestive of an existence of a stable long-run relationship between the financial sector and the economy. In addition, the results show that the economy granger-cause the financial sector index with no reverse causality observed. Policy implications of these findings are discussed in the paper.
\end{abstract}

Keywords: Granger Causality, financial services index, GDP, economy, Botswana

\section{Introduction}

The importance of the role played by capital markets in the global economy is undisputable. In this context, investors, policy-makers and the academia have played different roles in forming opinions and understanding the symbiotic relationship between financial sector performance and the state of an economy. Fundamental to this discourse is the search for the 'holy grail' of market efficiency. Numerous studies have been conducted on this subject matter and many findings documented, albeit with contradictory outcomes. It is this lack of consistency in the results from previous studies that warrants further investigation.

In the pursuance of knowledge and understanding of the interaction between financial sector performance and the state of the economy, three mainstream schools of thought have emerged. The first is the supply-leading school of thought which posits that financial development leads to economic growth (Vazakidis \& Adamopoulos, 2009; Bittencourt, 2012). The second school of thought advocates for the demand-following approach, arguing that economic growth drives financial development and performance (Odhiambo, 2004; 2010). The third school of thought argues for interdependent relationship and hence adopts a bidirectional causality approach in analysing the relationship between financial sector development and economic growth (Rousseau \& Vuthipadadorn, 2005).

Another interesting theoretical dimension was suggested by Patrick (1966) who hypothesised that the direction of causality between financial sector development and economic growth changes over the course of development. The study was suggestive that in the early stages of development (developing/underdeveloped countries) the supply-leading stimulates real capital formation and financial development; whereas in the latter stages of 
development (developed countries) the demand-leading catalyst was more prominent. This theoretical proposition is academically both appealing and robust, and hence a motivation for this study.

Botswana is a developing country that has an impressive economic transformation. Economic development has been rapid, compared with other developing countries, with the economy recording average growth rates of more than $10 \%$ per annum for most of the 1980s, largely emanating from revenue from diamonds (Akinboade, 1998). Furthermore, this rapid growth of the economy of Botswana transformed the country from one of the poorest in the world in 1966, to a middle income economy, with income per capita some eight or nine times that of the poorest countries in the 1980s; and by 1986, GDP at constant 1980 prices was P1 316 million, which was eleven times the 1966 estimate of P118 million (Akinboade, 1998). The Botswana Stock Exchange (BSE) is the local bourse which has experienced an equally impressive performance in a short period of time. To date, the BSE is one of Africa's best performing stock exchanges, averaging $24 \%$ aggregate return in the past decade. This has allowed the BSE to be the third largest stock exchange in terms of market capitalization, in Southern Africa (Botswana Stock Exchange, 2017).

In cognisance of the important role played by the financial sector in the wider economy, the BSE started a Domestic Company Financial Sector Index (DFSI) in 2013. As of to date, the BSE continues to be pivotal to Botswana's financial system, and in particular the capital market. The listed companies represent a spectrum of industries being; Banking, Financial Services, Wholesaling \& Retailing, Tourism, Mining, Energy, Property \& Trust, Security and ICT. In 2016, there were 34 listed entities on the BSE comprising of 24 domestic and 10 foreign companies, 41 listed bonds and four Exchange Traded Funds (Botswana Stock Exchange Annual Report, 2016). Still in the same year, the DCI depreciated by $11.3 \%$ to close the year at 9400.7 points, down from 10602.3 points at the end of 2015 . This decline in the DCI in 2016 was explained by the overall performance of the domestic companies, particularly the general slowdown in share prices due to the subdued operational and financial performance of some of the listed companies. In particular, out of the 24 listed domestic companies as at the end of 2016, 12 registered share price appreciation, 10 registered share price depreciation and two were unchanged (Botswana Stock Exchange Annual Report, 2016). Historically, the DCI has been heavily influenced by the Banking sector. However, the 2016 BSE Annual report reveals that the market capitalisation of the Banking sector relative to total domestic market capitalisation has declined from $46.9 \%$ in 2012 to $30.5 \%$ in 2016 which is a positive move, primarily due to additional listings in other sectors such as Retail \& Wholesaling and ICT (Botswana Stock Exchange Annual Report, 2016).

Besides sheer size, the financial sector plays an important role in the development of an economy. Levine (2000) indicated the important role of banks, as financial intermediaries, in the development of any economy. The study highlighted that if banks perform well, generally this is a sign that the economy is improving as individuals and corporations increase the demand for money. This increase in the demand for loans would be reflected in the balance sheet of banks, leading to an increase in their share price and ultimate increase in the financial sector index.

The BSE financial sector companies (at the time of the study) comprised of four commercial banks (First National Bank Botswana, Standard Chartered Bank Botswana, Barclays Bank Botswana and ABC Banc Botswana), the Botswana Insurance Holdings Limited and two other Financial Services Providers (Imara Holdings Limited and Letshego Financial Services Botswana).

\subsection{Research Gap and Objectives}

Limited studies have been conducted in Botswana with regards to the relationship between the financial sector performance and the economy. While the limited Botswana literature on the subject matter have discussed aspects of the relationship between financial sector development and the economy (Eita and Jordaan, 2010; Akinboade, 1998), there are critical aspects that are both wanting and warrant a different approach.

First is the significance of the study timeframe. Previous research does not incorporate the critical periods in financial markets history over which the global economy experienced the economic cycle of the boom years (2003-2006), followed by a recession (2007-2010) and then finally the recovery period (2010 and beyond). This global cycle provides an opportunity for new insights into how financial sector performance relates to the economy.

Second, it is the secondary objective of the study to improve on measures used in previous studies. In particular, this study will use different measures to proxy financial sector. As already mentioned, the DFSI is a relatively new index and hence none of the previous studies have utilised this all-compassing measure. For example, Akinboade (1998) used non-mineral, GDP while Eita and Jordaan (2010) used the ratio of liquid liabilities to GDP (M3/GDP) to proxy financial sector, measures that do not aptly represent the Botswana financial sector.

Third, while previous studies have delved on financial sector development (Eita and Jordaan, 2010; Akinboade, 
1998), this study will explore the perspective of financial sector profitability. The study will use the DFSI to proxy profitability of the financial sector on the premise that the index is a composite share price movement, thus a reflection of changes in investor sentiments on future expected earnings of the underlying assets or companies.

\section{Literature Review}

Studies on the relationship between financial sector development and economic growth can be traced back to Schumpeter (1911) who asserted that financial institutions and the prevalance of entrepreneurship are necessary and sufficient conditions for economic development. Since then a myriad of studies have collected empirical evidence that overwhelmingly support the notion of a positive relationship. For example, positive correlation has been found to exist between stock market development and economic growth (Atje and Jovanovic, 1993; Beck and Levine, 2004). Also, a study using time series data (1980-1995) conducted in the Middle Eastern and North African countries on the association of both the stock market and banks to economic growth concluded that with well-functional financial sector, stock markets can give a big boost to economic development (Rousseau and Wachtel, 2000).

Similarly, Levine, Loayza and Beck (1999) evaluated whether the exogenous component of financial intermediary development influences economic growth. Using traditional cross-section, instrumental variable procedures and dynamic panel techniques, the study found that the exogenous components of financial intermediary development to be positively associated with economic growth. However, Pagano (1993) caveated this relationship by posited that financial development is too generic a term and hence researchers must be more specific if the impact on growth is to be more meaningfully gauged.

Some studies have been conducted in Sub-Saharan Africa. The banking sector has been found to be the leading force behind the growth of African Stock Markets between 1990 and 2006 (Andrianaivo \& Yartey, 2007). Yartey and Adjasi (2007) explored the critical challenges of stock market development in countries including Nigeria, Ghana and Tanzania and found stock markets to have contributed to the growth of large corporations, although evidence was inconclusive on the impact of stock markets on the wider economic growth.

There is limited understanding on the relationship between financial sector development and economic growth in Botswana due to the limited studies that have been conducted. Further, very little cue can be taken from studies conducted in other Southern African countries owing to the inconclusiveness of the results (e.g. Yartey \& Adjasi, 2007). Only a few papers cover the growth of the Botswana Stock Exchange and mention that such growth is supported by a growing banking and financial services sector (Eiter \& Jordaan, 2007). Eiter and Jordaan, (2007) examined the causal relationship between financial development and economic growth in Botswana. Granger causality through cointegrated vector autoregression methods was applied to test the causality between these economic factors in Botswana for the period 1977-2006. The paper found evidence of supply-leading and demand-leading theories when using different proxies for financial development. For example, when the ratio of deposit liabilities to non-mineral GDP is used as a proxy for financial development, the causality runs from financial development to economic growth, which supports Schumpeter's supply-leading theory. In contrast, causality runs from economic growth to financial development when the ratio of private sector credit to non-mineral GDP is used as a proxy for financial development; thus, supporting the demand-leading theory (Eiter \& Jordaan, 2007). With a view to both improve on the robustness and reliability of the results, this study will use a single proxy for financial development.

The approach of investigating the relationship between financial sector development and economic growth without due regard to the causal effect has been criticised. Patrick (1966), in a study carried in underdeveloped countries, opined that the causal nature of the relationship between these variables is a matter that should be employed to better understand the intricacies of the relationship, a prerequisite to a more robust theoretical framework and undertaking. Some research has been undertaken in this direction and different theoretical opinions have emerged and empirically tested. For example, some researchers, using national cross-sectional data, argue that financial sector is a precursor to economic growth (Gelb, 1989; Fry, 1997; King \& Levine, 1993; Levine, 1997, 1998; Rajan \& Zingales, 1998; Levine \& Zervos, 1998), while others argue that economic growth drives demand for financial instruments, and thus financial sector development (Robinson, 1952; Jung, 1986 \& Ireland, 1994). It is in this light that this paper is focused on the directional or causality relationship between financial development and economic growth within the Botswana context.

In the context of a developing economy, Ndako (2009) (Note 1) used quarterly time series data (1983 - 2007) to examine causal relationship between stock market, banks and economic growth in South Africa. The study concluded that long-run bi-directional causality exists between financial development and economic growth in the banking system; but unidirectional causality was found from economic growth to stock market system in long-run., 
A similar study by Calderón and Lin Liu (2002) pooled data of 109 developing and industrial countries from 1960 to 1994 in order to examine the direction of causality between financial development and economic growth. The study found that (i) financial development generally leads to economic growth; (ii) Granger causality from financial development to economic growth and Granger causality from economic growth to financial development coexisted; (iii) financial deepening contributed more to the causal relationships in the developing countries than in the industrial countries.

Another study was carried by Demetriades and Hussein (1996) on causality tests between financial development and real GDP. Though the study findings provided little support to the view that finance is a leading sector in the process of economic development, considerable evidence of bi-directionality and some evidence of reverse causation was found. The study highlighted the fact that causality patterns vary across countries. To this extent, countries and economies are not homogeneous entities and inferences should be done with great caution.

Using annual data of 56 countries, of which 19 were industrialised countries, Jung (1986) studied not only the existence and characterization of causality, but also its temporal behaviour between financial and real development. Using currency ratio as a measure of financial development, least developing countries (LDCs) were characterized by the causal direction running from financial to economic development, and developing countries (DCs) by the reverse causal direction, regardless of which causality concept is employed. Thus the study highlighted the importance of the stage of development as a mediating factor in the relationship.

Shun, Morris and Sun (2001) used a Granger causality procedure to investigate the relationship between financial development and growth. As opposed to a time series model used in many studies, this study estimated an Auto Regressive (VAR) model for nine OECD countries and China. The results presented a bi-directional relationship in half of the countries and reverse causality in three others. Though evidence showed little support that finance leads to economic development, the study cautioned that a general conclusion based on this outcome should be avoided. Meanwhile, Arestis and Demetriades (1997) examined the empirical literature on the relationship between financial development and economic growth from two approaches. The first approach was the issue of whether the financial system can contribute to the process of economic growth. The econometric evidence reviewed using time-series estimations on individual countries suggested that the results exhibit substantial variation across countries, even when the same variables and estimation methods are used. The second approach was the use of time series methods and data from five developed economies in examining the relationship between stock market development and economic growth. The findings revealed that, although both banks and stock markets may be able to promote economic growth, the effects of the former are more pronounced. Additionally, they showed that the contribution of stock markets on economic growth may have been exaggerated by studies that utilize cross-country growth regressions

In summary, there are three important observations from the literature: (i) a relationship does exist between financial development and economic growth, (ii) there is a causal effect in the nature of this relationship; (iii) countries are heterogeneous and cross-country studies in Africa are inconclusive; and (iv) a country's stage of economic development is mediating factor in the relationship, i.e. while developed nations tend to show a bi-directional causality relationship between financial development and economic growth, LDCs tend to show causality running from financial to economic development and no reverse causality.

These are observations that form the premise of this study's research hypotheses:

$\boldsymbol{H}_{\mathbf{1}}$ There is a causal relationship running from Financial Sector Index to GDP

$\boldsymbol{H}_{\boldsymbol{2}}$ There is a causal relationship running from GDP to Financial Sector Index

\section{Methodology}

The principal objective of this study is to test for the relationship between financial sector development and economic growth, with particular emphasis on the profitability aspect of financial sector. An econometric framework will be used for analysis of Botswana's economic data over a 10 year period (2003-2013).

In constructing the Financial Sector Index (FSI), the study uses the daily market capitalisation of the financial services and banking companies listed in the domestic board of the Botswana Stock Exchange (BSE). The data will be obtained from the Domestic Companies Financial Sector Index of the BSE. Economic growth, on the other hand, will be measured using the national Gross Domestic Product (GDP) figures. This data will be sourced from the Bank of Botswana (Botswana Central Bank) statistics.

The Granger-causality test (Granger, 1969), and in particular the cointergation and error-correction model, will then 
be used to examine the direction of causality between financial development and economic growth.

Engle and Granger (1987) proposed a two-step method of testing for cointegration which looks for a unit root in the residuals of a first-stage regression. Before testing for cointergration, the study first assesses whether FSI and GDP are unit root processes. Cointegrated variables share common stochastic and deterministic trends and tend to move together through time in a stationary manner even though the two variables in this study may be non-stationary. This paper therefore tests the null hypothesis of $x_{t}, y_{t} \neq I(0)$ where $x_{t}$ and $y_{t}$ are the GDP and financial sector index and are not unit root stationerySince Granger causality test may depend critically on the number of lag structure term included (Granger, 1969), testing for cointergration will therefore be presceded by determination of the optimal lag structure in the model. In determining the optimal lags, the Akaike information criterion (AIC) and the Schwarz information criterion (SC) will be used by setting maximum on e-views. The number of observations in the study allow for the maximum possible lag structure to be 12 .

The paper assesses the cointergation between FSI and GDP by studying the following regression:

$$
\begin{aligned}
& \Delta Y_{t}=\alpha_{o}+\sum_{t=1}^{n} \alpha_{1 i} \Delta Y_{t-1}+\sum_{j=1}^{m} \alpha_{2 i} \Delta X_{t-j}+\alpha_{3}\left(Y_{t-1}-\gamma X_{t-1}\right)+\mu_{1 t} \\
& \Delta X_{t}=\beta_{o}+\sum_{t=1}^{n} \beta_{1 i} X_{t-1}+\sum_{j=1}^{m} \beta_{2 i} \Delta Y_{t-j}+\beta_{3}\left(Y_{t-1}-\gamma X_{t-1}\right)+\mu_{2 t}
\end{aligned}
$$

The null hypothesis of no cointegration among variables in equation 1 is tested (i.e., H0: $1 Y \gamma=2 Y \gamma=0$ ) against the alternative hypothesis (i.e., H1: $1 Y \gamma \neq 2 Y \gamma \neq 0$ ) using the F-test for the significance of the lagged levels coefficient in equation 2. In equation 2, when the GDP is the dependent variable, the null hypothesis of no cointegration among variables is tested (i.e., H0: $1 X \gamma=2 \mathrm{X} \gamma=0$ ) against the alternative hypothesis (i.e., H1: $1 \mathrm{X} \gamma \neq 2 \mathrm{X} \gamma \neq 0$ ) using the F-test for the joint significance of the lagged levels coefficient in equation 2. If the estimated F-statistics is greater than the upper bound critical value, it can be concluded that the variables in question are cointegrated. Also, if the estimated F-statistics falls between the lower and the upper bound critical values, the decision about cointegration among the variables involved is inconclusive.

The presence of cointegration indicates that there is a long-run relationship between the variables and it is appropriate to test the direction of causality so once cointegration between the FSI and GDP has been established; now the study moves to test the causality.

The study will conduct a null test to establish if the index granger-cause the growth in the economy and also confirm the opposite. $\mathrm{H}_{0}=\alpha_{11}=\alpha_{11}=\ldots \ldots \alpha_{1 \mathrm{~m}}=0$, will imply that the economy does not granger-cause an appreciation in the index similarly, $\mathrm{H}_{0}=\beta_{11}=\beta_{11}=. . \beta_{1 \mathrm{~m}}=0$ is used to confirm that the index granger-causes the economic growth.

\section{Test Results}

Quarterly time series data was for Real GDP figures was obtained from the Bank of Botswana (BoB) archives while figures used to construct the Financial Sector Index (FSI) were obtained from the Botswana Stock Exchange (BSE) daily trading summary.

The raw daily FSI data converted to quarterly figures for uniformity with the GDP data. Brooks (2008) pointed out that it is not advisable to use daily data in research as daily data normally contains a lot of noise/ error term but the error term reduces with time as the price reverts to its true price.

In keeping with the Engle and Granger (1987) proposal for a two-step method, unit root test was used to ascertain the order of integration in the stationary test. Because of limited sample size, other tests (such as KPSS, Elliot-Rothernberg-Stock Point-Optimal and Ng-Perron) which require many observations were not used. Instead the Augmented Dickey Fuller (ADF) test, used to test for unit root, was used and the results are presented in Table 1. 
Table 1. ADF unit root results with no differential

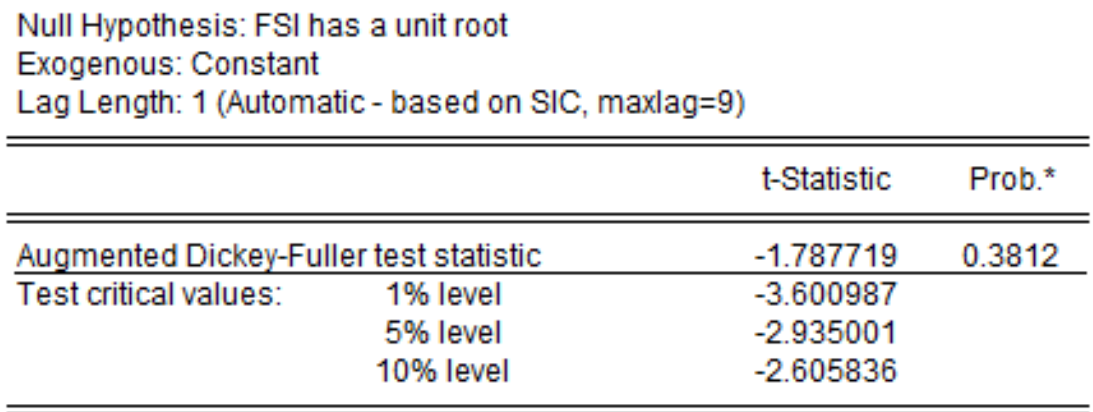

*MacKinnon (1996) one-sided p-values.

Null Hypothesis: GDP has a unit root

Exogenous: Constant

Lag Length: 0 (Automatic - based on SIC, maxlag=9)

\begin{tabular}{lccc}
\hline \hline & t-Statistic & Prob. \\
\hline \hline Augmented Dickey-Fuller test statistic & -1.126629 & 0.6964 \\
\hline Test critical values: & 1\% level & -3.596616 & \\
& $5 \%$ level & -2.933158 & \\
& $10 \%$ level & -2.604867 & \\
\hline \hline
\end{tabular}

*MacKinnon (1996) one-sided p-values.

Source: Eviews.

The unit root test results show that the GDP and FSI have a t-statistic of -1.78 and -1.12 respectively, which are above the critical points, and thus the null hypothesis cannot be rejected meaning that the FSI and real GDP have a unit root. In sum, both variables are non-stationary. To make the variables stationary, the study tested the unit root in the first difference and the results are shown below in Table 2.

Table 2. ADF unit root results at the first difference

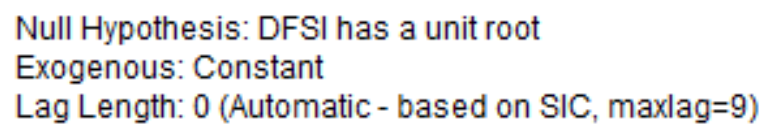

\begin{tabular}{lccc}
\hline \hline & t-Statistic & Prob. $^{*}$ \\
\hline \hline Augmented Dickey-Fuller test statistic & -4.366627 & 0.0012 \\
\hline Test critical values: $\quad$ 1\% level & -3.600987 & \\
& $5 \%$ level & -2.935001 & \\
& $10 \%$ level & -2.605836 & \\
\hline \hline
\end{tabular}

*MacKinnon (1996) one-sided p-values. 


Null Hypothesis: DGDP has a unit root
Exogenous: Constant
Lag Length: 0 (Automatic - based on SIC, maxlag=9)
\begin{tabular}{lccc}
\hline & t-Statistic & Prob. \\
\hline \hline Augmented Dickey-Fuller test statistic & -7.379019 & 0.0000 \\
\hline Test critical values: $1 \%$ level & -3.600987 & \\
& $5 \%$ level & -2.935001 & \\
& $10 \%$ level & -2.605836 & \\
\hline \hline
\end{tabular}

*MacKinnon (1996) one-sided p-values.

The results indicated t-statistic values of -4.37 and -7.38 for FSI and real GDP respectively. Both stationary test results using the first differences indicated statistical significance, an indication that the data was stationary, and thus the null hypothesis rejected at a confidence level of $1 \%$.

Next was the test for optimality in the lag structure as a prerequisite to testing for cointegration (Granger, 1969). According to Engle and Granger (1987) the most common and widely used information criterions for the determination of the optimal lag structure are the Akaike information criterion (AIC) and the Schwarz information criterion (SC). Dudson(1991) showcased that both test are similar and using one over the other would not have any significant effect on the results. The general rule in determining the optimal lag is to choose the lag that gives the lowest Akaike information criterion value.

The number of observations in the study allow for the maximum possible lag structure to be 12 . The appropriate lag order, up to the predetermined maximum (12) can be determined using the criteria mentioned previously. The results of the tests to determine the optimal lag structure are reported in table 3 below. Using the Akaike Information Criterion (AIC) to determine the optimal lag structure, lag nine (9) gives the lowest information criterion value, hence most optimal for application.

Table 3. Optimal lag structure results using AIC and SIC

\begin{tabular}{lll}
\hline $\begin{array}{l}\text { Lag } \\
\text { specifications }\end{array}$ & AIC & SC \\
\hline $\mathbf{2}$ & 34.19 & 34.69 \\
$\mathbf{3}$ & 34.28 & 34.88 \\
$\mathbf{4}$ & 34.41 & 35.18 \\
$\mathbf{5}$ & 34.58 & 35.54 \\
$\mathbf{6}$ & 34.44 & 35.58 \\
$\mathbf{7}$ & 34.36 & 35.70 \\
$\mathbf{8}$ & 33.93 & 35.47 \\
$\mathbf{9}$ & 33.45 & 35.57 \\
$\mathbf{1 0}$ & 33.66 & 35.98 \\
$\mathbf{1 1}$ & 33.81 & 35.94 \\
$\mathbf{1 2}$ & 33.96 & 36.29 \\
\hline
\end{tabular}

On the basis of the unit root test above, the cointegration test was performed to investigate long term relationship 
between the two variables. The guiding assumptions for testing for cointegration are:

i. No deterministic trends \& cointegrating relationships that do not contain intercepts

ii. No deterministic trends \& cointegrating relationships that have intercepts

iii. Linear trends but cointegrating relationships that have only intercepts

iv. The series $\&$ cointegrating relationships that have linear trends

v. Quadratic trends \& cointegrating relationships that have linear trends

In keeping with an approach used by Hiaso (2003), the test for integration assumed a linear trend and that the relationship has intercepts. Table 4 is a presentation of cointegration test results, followed by a summary presentation of the output on the other assumptions.

Table 4. Cointegration test: Information criteria by rank and model

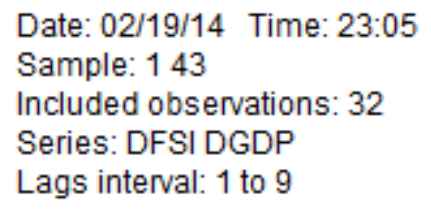

Selected $\left(0.05\right.$ level $\left.^{\star}\right)$ Number of Cointegrating Relations by Model

\begin{tabular}{cccccc}
\hline \hline Data Trend: & None & None & Linear & Linear & Quadratic \\
\hline Test Type & No Intercept & Intercept & Intercept & Intercept & Intercept \\
& No Trend & No Trend & No Trend & Trend & Trend \\
Trace & 0 & 1 & 2 & 0 & 2 \\
Max-Eig & 0 & 1 & 2 & 0 & 2 \\
\hline \hline
\end{tabular}

${ }^{*}$ Critical values based on MacKinnon-Haug-Michelis (1999)

Information Criteria by Rank and Model

\begin{tabular}{|c|c|c|c|c|c|}
\hline Data Trend: & None & None & Linear & Linear & Quadratic \\
\hline $\begin{array}{c}\text { Rank or } \\
\text { No. of CEs }\end{array}$ & $\begin{array}{l}\text { No Intercept } \\
\text { No Trend }\end{array}$ & $\begin{array}{l}\text { Intercept } \\
\text { No Trend }\end{array}$ & $\begin{array}{l}\text { Intercept } \\
\text { No Trend }\end{array}$ & $\begin{array}{l}\text { Intercept } \\
\text { Trend }\end{array}$ & $\begin{array}{l}\text { Intercept } \\
\text { Trend }\end{array}$ \\
\hline \multicolumn{6}{|c|}{ Log Likelihood by Rank (rows) and Model (columns) } \\
\hline 0 & -513.5639 & -513.5639 & -513.5212 & -513.5212 & -513.2963 \\
\hline 1 & -510.2161 & -505.5087 & -505.4798 & -503.8558 & -503.6373 \\
\hline 2 & -508.8271 & -503.0579 & -503.0579 & -500.7105 & -500.7105 \\
\hline & \multicolumn{5}{|c|}{ Akaike Information Criteria by Rank (rows) and Model (columns) } \\
\hline 0 & 34.34774 & 34.34774 & 34.47007 & 34.47007 & 34.58102 \\
\hline 1 & 34.38851 & $34.15680^{*}$ & 34.21749 & 34.17849 & 34.22733 \\
\hline 2 & 34.55169 & 34.31612 & 34.31612 & 34.29440 & 34.29440 \\
\hline \multicolumn{6}{|c|}{ Schwarz Criteria by Rank (rows) and Model (columns) } \\
\hline 0 & $35.99670^{\star}$ & $35.99670^{*}$ & 36.21063 & 36.21063 & 36.41319 \\
\hline 1 & 36.22067 & 36.03477 & 36.14127 & 36.14807 & 36.24272 \\
\hline 2 & 36.56708 & 36.42312 & 36.42312 & 36.49301 & 36.49301 \\
\hline
\end{tabular}

From the results in Table 4, five test types were established and the number of cointegrating equations were generated under each. For example, under the assumptions 1 of no intercept and no trend, and 4 of intercept and 
trend only, the equations did not have any cointegrating equation. Under the assumption 2 of intercept and no trend, a single cointegration was observed. However, two cointegrating equations at a significance level of 5\% where observed under the $3^{\text {rd }}$ and $5^{\text {th }}$ assumptions of intercept and no trend and that of intercept and trend respectively. Having established some existence of cointegrating equations between the two variables; it implies the existence of a long-run causality in at least one direction (unilateral causality) between the two variables.

As the research focuses on a model that assumes intercept and no trend, Table 5 below shows a closer look at the cointergration test, from the table one can see that the variables are cointegrated with a significance level of 5\%.

Table 5. Cointergration; intercept with no trend

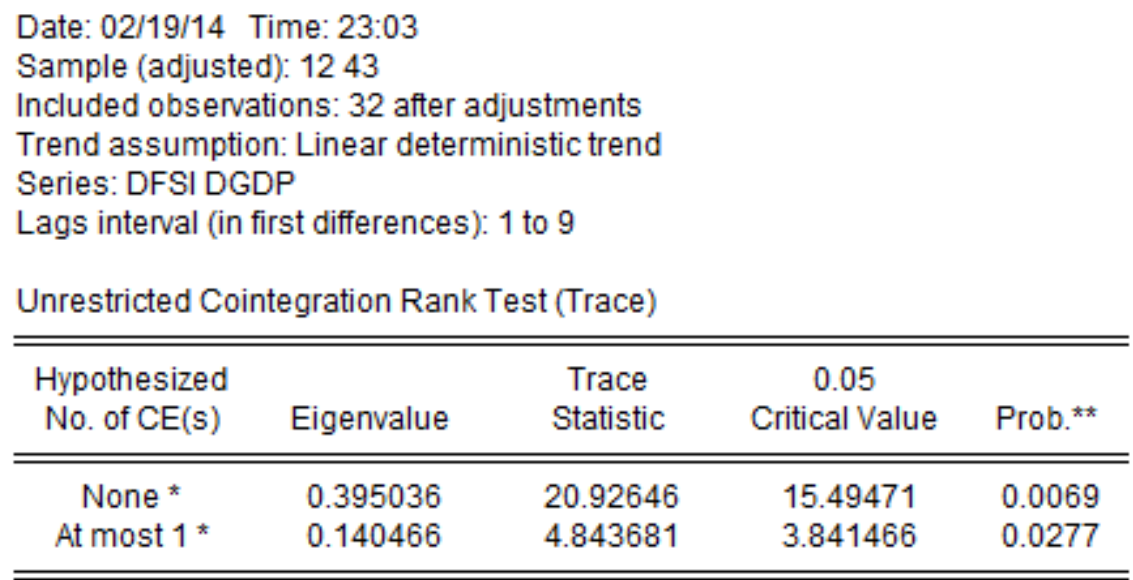

Trace test indicates 2 cointegrating eqn(s) at the 0.05 level

${ }^{*}$ denotes rejection of the hypothesis at the 0.05 level

**MacKinnon-Haug-Michelis (1999) p-values

Source: eViews

Having established that the variables are cointegrated according to Duca (2007), "If two or more time-series are cointegrated, then there must be Granger causality between them - either one-way or in both directions. However, the converse is not true". From the statement the expectation will be that there is causality with our variables.

The final step was to perform the Granger Causality test. Table 6 shows the results of the Granger Causality test.

Table 6. Granger Causality Tests

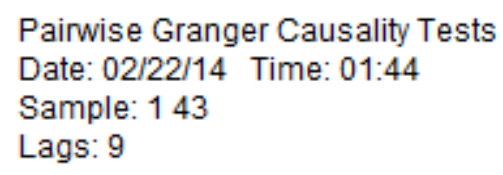

\begin{tabular}{lccc}
\hline \hline Null Hypothesis: & Obs & F-Statistic & Prob. \\
\hline \hline GDP does not Granger Cause FSI & 33 & 2.23334 & 0.0860 \\
FSI does not Granger Cause GDP & & 1.66839 & 0.1884 \\
\hline \hline
\end{tabular}

The results of the Granger Causality show that the null hypothesis that GDP does not Granger Cause FSI has to be rejected with a p-value of 0.086 at a significance level of $10 \%$ while a second test showed that the null hypothesis that FSI does not Granger Cause GDP cannot be rejected with a p-value 0.1884. 
The results infer that the alternative hypothesis that GDP does Granger Cause the FSI has to be accepted. In the second test, a common definition of Granger Causality, in the case of two time-series variables, $\mathrm{X}$ and $\mathrm{Y}$ is: " $\mathrm{X}$ is said to Granger-cause $\mathrm{Y}$ if $\mathrm{Y}$ can be better predicted using the histories of both $\mathrm{X}$ and $\mathrm{Y}$ than it can by using the history of $\mathrm{Y}$ alone."

\section{Discussion and Conclusions}

This study was set on the backdrop of three key observations made from the literature: (i) there is affirmation of a relationship between financial development and economic growth; (ii) there is a causal effect in the nature of this relationship; (iii) countries are heterogeneous and cross-country studies in Africa are inconclusive; and (iv) a country's stage of economic development is mediating factor in the relationship.

The contribution of this study to extant literature was in; (i) the significance of the study timeframe that accounted for a historical global economic cycle (2003-2013); (ii) improving measures used for Financial Sector by using the Botswana Financial Sector Index; (iii) exploring the perspective of financial sector profitability, instead of the conventional financial development approach.

Granger Causality test results were indicative that Real GDP has causality effect on Financial Sector profitability. By extension, these results laid credence to the demand-following response hypothesis. The implication of these findings to Botswana is that the economy should growth first in order to stimulate financial sector development. However, no causal relationship was found running from Financial Sector Profitability to GDP, thereby dispelling the "wealth effect" supposition.

These findings are consistent to those of other similar studies (Mauro 2003, Rousseeu and Wachtel 2000, Adjasi and Biekpe 2005). It should also be noted that these results contradicted by Duca (2007) who found out that Real Gross Domestic Product is the one which granger causes the Financial Sector Index.

Notwithstanding the empirical inconclusiveness alluded to above, Kar and Pentecost (2000) cautioned that the direction of causality between financial sector and economic growth is also sensitive to the choice of proxies for financial development. While this study used financial sector index, other studies have used different measures, i.e. stock market turnover ratio (Duca, 2007) and the ratio of credit provided by banks to private sector (Adebola\& Dahalan, 2011)

Penm (2003), on the other hand, indicated that the very existence of a causality relationship between the financial sector index and the economy has been said to suggest some form of inefficiency in the market.

It is increasingly evident that the causality relationship between financial development and economic growth is both complicated and difficult, owing to such myriad of factors such as variable measures, stage of economic development, market efficiency and study timeframe. However, there is empirical traction on that developed nations tend to show a bi-directional causality relationship between financial development and economic growth, while the developing economies tend to show causality running from financial to economic development, with no reverse causality. The results of this study contradict this notion, a matter that could be attributable to Botswana's unique position as a middle income developing country (Akinboade, 1998), and the nature of the measure for Financial Sector used. These are areas that warrant further study.

\section{References}

Adebola, S. S., \& Dahalan, J. (2011). Financial development and economic growth: The role of stock markets and banking sector in Nigeria. Journal of Sustainable Development in Africa, 13(7).

Adjasi, C., \& Biekpe, B. (2005). Stock market returns and exchange rate dynamics in selected African countries: A bivariate analysis. The African Finance Journal, 8(Part 2). https://doi.org/10.1108/20400701111165623

Adusei, M. (2013). Does Finance Promote Growth In Botswana?. Research in Applied Economics, 5(2), 70. https://doi.org/10.5296/rae.v5i2.3821

Akinboade, O. A. (1998). Financial Development and Economic Growth in Botswana: A test for Causality/Développement Financier et Croissance économique au Botswana: Un Test de Causalité. Savings and Development, 331-348. Retrieved from https://www.jstor.org/stable/25830662

Al-Yousif, Y. K. (2002). Financial development and economic growth: another look at the evidence from developing countries. Review of Financial Economics, 11(2), 131-150. https://doi.org/10.1016/S1058-3300(02)00039-3

Andrianaivo, M., \& Yartey, C. A. (2009). Understanding the growth of African financial markets. IMF Working Papers, 1-40. 
Arestis, P., \& Demetriades, P. (1997). Financial development and economic growth: assessing the evidence. The Economic Journal, 107(442), 783-799. https://doi.org/10.1111/j.1468-0297.1997.tb00043.x

Arestis, P., Demetriades, P. O., \& Luintel, K. B. (2001). Financial development and economic growth: the role of stock markets. Journal of Money, Credit and Banking, 16-41. Retrieved from https://www.jstor.org/stable/2673870

Atje, R., \& Jovanovic, B. (1993). Stock markets and development. European Economic Review, 37(2), 632-640.

Bagehot, W., Street, L., \& Homewood, I. (1873). Richard D. Irwin, Homewood, Illinois [1962 edition]. https://doi.org/10.1016/0014-2921(93)90053-D

Bakar, N. M. A., \& Tahir, I. M. (2009). Applying multiple linear regression and neural network to predict bank performance. International Business Research, 2(4), 176.

Beck, T., \& Levine, R. (2004). Stock markets, banks, and growth: Panel evidence. Journal of Banking \& Finance, 28(3), 423-442, https://doi.org/10.1016/S0378-4266(02)00408-9

Bittencourt, M. (2012). Financial development and economic growth in Latin America: Is Schumpeter right?. Journal of Policy Modeling, 34(3), 341-355, https://doi.org/10.1016/j.jpolmod.2012.01.012

Botswana, B. O. (2013). Annual Report (Gaborone, Trans.).

Botswana Stock Exchange. (2017). Role in Botswana. Retrieved 26 April 2017, from http://www.bse.co.bw/abt_us/role_in_botswana.php

Broby, D. (2011). Equity Index Construction. The Journal of Index Investing, 36-37.

Brooks, C. (2010). Introductory Econometric for Finance. Cambridge: Cambridge University Press.

Calderón, C., \& Liu, L. (2003). The direction of causality between financial development and economic growth. Journal of Development Economics, 72(1), 321-334. https://doi.org/10.1016/S0304-3878(03)00079-8

Christopoulos, D. K., \& Tsionas, E. G. (2004). Financial development and economic growth: evidence from panel unit root and cointegration tests. Journal of Development Economics, 73(1), 55-74. https://doi.org/10.1016/j.jdeveco.2003.03.002

Demetriades, P. O., \& Hussein, K. A. (1996). Does financial development cause economic growth? Time-series evidence from 16 countries. Journal of Development Economics, 51(2), 387-411. https://doi.org/10.1016/S0304-3878(96)00421-X

Demetriades, P. O., \& Luintel, K. B. (1996). Financial development, economic growth and banking sector controls: evidence from India. The Economic Journal, 359-374. https://doi.org/10.2307/2235252

Duca, G. (2007). The relationship between the stock market and the economy: experience from international financial markets. Bank of Valletta Review, 36(3), 1-12.

Eita, J. H., \& Jordaan, A. C. (2007). A causality analysis between financial development and economic growth for Botswana. Retrieved from https://hdl.handle.net/10520/EJC33747

Engle, R. F., \& Granger, C. W. (1987). Co-integration and error correction: representation, estimation, and testing. Econometrica: Journal of the Econometric Society, 251-276. Retrieved from https://www.jstor.org/stable/1913236

Exchange, B. S. (2008, 2009, 2010, 2011, 2012). Annual Reports.

GC, S. B. (2006). Stock market and economic development: a causality test. The Journal of Nepalese Business Studies, 3(1). Retrieved from https://ssrn.com/abstract=1566002

Granger, C. W. (1969). Investigating causal relations by econometric models and cross-spectral methods. Econometrica: Journal of the Econometric Society, 424-438. https://doi.org/10.2307/1912791

Hassan, M. K., Sanchez, B., \& Yu, J.-S. (2011). Financial development and economic growth: New evidence from panel data. The Quarterly Review of Economics and Finance, 51(1), 88-104. https://doi.org/10.1016/j.qref.2010.09.001

Ireland, P. N. (1994). Money and Growth: An Alternative Approach. American Economic Review, 84(1), 47-65. Retrieved from https://www.jstor.org/stable/2117970

Jung, W. S. (1986). Financial development and economic growth: international evidence. Economic Development 
and Cultural Change, 34(2), 333-346. https://doi.org/10.1086/451531

Kar, M., \& Pentecost, E. J. (2000). Financial development and economic growth in Turkey: further evidence on the causality issue. Economic Research Paper, 27.

Khan, M. M. S., \& Semlali, M. A. S. (2000). Financial development and economic growth: an overview. International Monetary Fund.

King, R. G., \& Levine, R. (1993). Finance and growth: Schumpeter might be right. The Quarterly Journal of Economics, 717-737. https://doi.org/10.2307/2118406

Levine, R. (1997). Financial development and economic growth: views and agenda. Journal of Economic Literature, 35(2), 688-726.

Levine, R. (2000). Bank-based or market-based financial systems: which is better?. University of Minnesota, mimeo.

Levine, R., Loayza, N., \& Beck, T. (2000). Financial intermediation and growth: Causality and causes. Journal of Monetary Economics, 46(1), 31-77. https://doi.org/10.1016/S0304-3932(00)00017-9

Levine, R., \& Zervos, S. (1998). Stock markets, banks, and economic growth. American Economic Review, 537-558. Retrieved from https://www.jstor.org/stable/116848

Malkiel, B. G., \& Fama, E. F. (1970). Efficient capital markets: A review of theory and empirical work. The Journal of Finance, 25(2), 383-417. Retrieved from https://www.jstor.org/stable/2325486

Mauro, P. (2003). Stock returns and output growth in emerging and advanced economies. Journal of Development Economics, 71(1), 129-153. https://doi.org/10.1016/S0304-3878(02)00136-0

Odhiambho, N. (2004). Financial development and economic growth in South Africa. Department of Economics, University of Fort Hare, South Africa.

Odhiambo, N. M. (2004). Is financial development still a spur to economic growth? A causal evidence from South Africa. Savings and Development, 47-62. Retrieved from https://www.jstor.org/stable/25830849

Pagano, M. (1993). Financial markets and growth: an overview. European Economic Review, 37(2-3), 613-622.

Patrick, H. T. (1966). Financial development and economic growth in underdeveloped countries. Economic Development and Cultural Change, 14(2), 174-189. https://doi.org/10.1086/450153

Rousseau, P. L., \& Wachtel, P. (2000). Equity markets and growth: cross-country evidence on timing and outcomes, 1980-1995. Journal of Banking \& Finance, 24(12), 1933-1957. https://doi.org/10.1016/S0378-4266(99)00123-5

Schumpeter, J. (1911). The Theory of Economic Development, Cambridge, MA: Harvard University.

Shan, J. Z., Morris, A. G., \& Sun, F. (2001). Financial Development and Economic Growth: An Egg-and-Chicken Problem?. Review of International Economics, 9(3), 443-454. https://doi.org/10.1111/1467-9396.00291

Vazakidis, A., \& Adamopoulos, A. (2009). Financial development and economic growth an empirical analysis for Greece. American Journal of Applied Sciences, 6(7), 1410.

Yartey, C. A., \& Adjasi, C. K. (2007). Stock market development in Sub-Saharan Africa: Critical issues and challenges. International Monetary Fund. Retrieved from https://ssrn.com/abstract=1012992

\section{Note}

Note 1. Stocks markets are generally viewed as the predictor of the economy but Ndako(2010) using ARDL-Bounds testing procedure to test stock market development and economic growth in South Africa refused such claim whereas an earlier research by Odhiambo (2004) in the same country supported such claim.

\section{Copyrights}

Copyright for this article is retained by the author(s), with first publication rights granted to the journal.

This is an open-access article distributed under the terms and conditions of the Creative Commons Attribution license (http://creativecommons.org/licenses/by/4.0/). 